\title{
Flocculation and Expression of FLO Genes of a Saccharomyces cerevisiae Mezcal Strain with High Stress Tolerance
}

\section{Israel Vergara-Álvarez',2®, Francisco Quiroz-Figueroa ${ }^{3}$, María Concepción Tamayo- -Ordóñez ${ }^{1,4} \oplus$, Amanda Alejandra Oliva-Hernández®®, Claudia Patricia Larralde- -Corona'® and José Alberto Narváez-Zapata ${ }^{1 *} \odot$}

${ }^{1}$ National Polytechnic Institute (Instituto Politécnico Nacional), Center for Genomic Biotechnology, Blvd del Maestro s/n esq, Elías Piña Col. Narciso Mendoza, C.P. 88710, Reynosa (Tamaulipas), Mexico

${ }^{2}$ Aix-Marseille University, LCB (UMR7283), CNRS, Marseille, France

${ }^{3}$ National Polytechnic Institute (Instituto Politécnico Nacional), CIIDIR-IPN Unidad Sinaloa, Blvd. Juan de Dios Bátiz Paredes no. 250, Col. San Joachin, C.P. 81101 Guasave (Sinaloa), Mexico ${ }^{4}$ Genetic Engineering Laboratory, Department of Biotechnology, Faculty of Chemical Sciences, Autonomous University of Coahuila, Saltillo Unit, Mexico

Received: 26 September 2018 Accepted: 8 November 2019
${ }^{*}$ Corresponding author:

E-mail:jnarvaez@ipn.mx

\section{SUMMARY}

Mezcal is a distillate produced by spontaneous fermentation of the must obtained from stalks of Agave spp. plants that are cooked and pressed. Agave must contains a high amount of fructose and phenolic compounds, and fermentation usually occurs under stressful (and uncontrolled) environmental conditions. Yeasts capable of growing under such conditions usually display advantageous biological and industrial traits for stress tolerance such as flocculation. In this study, seven Saccharomyces cerevisiae strains isolated from mezcal must were exposed to temperatures ranging between 10 and $40^{\circ} \mathrm{C}$, and to different sugar sources (fructose or glucose). Yeasts grown in fructose increased their stress tolerance, determined by colony count in a microdrop assay, under low temperature $\left(10^{\circ} \mathrm{C}\right)$ compared to the growth at $40^{\circ} \mathrm{C}$ on solid cultures. The most stress-tolerant mezcal strain (Sc3Y8) and a commercial wine (Fermichamp) strain, used as control, were grown under fermentation conditions and exposed to long-term temperature stress to determine their performance and their potential for flocculation. Compared to glucose, fermentation on fructose increased the metabolite accumulation at the end of culture, particularly at $40^{\circ} \mathrm{C}$, with $2.3,1.3$ and 3.4 times more glycerol ( $8.6 \mathrm{~g} / \mathrm{L})$, ethanol $(43.6 \mathrm{~g} / \mathrm{L})$ and acetic acid $(7.3 \mathrm{~g} / \mathrm{L})$, respectively. Using confocal microscopy analysis, we detected morphological changes such as aggregation and wall recognition at the level of budding scars in yeast, particularly in the Sc3Y8 strain when it was exposed to $40^{\circ} \mathrm{C}$. The analysis confirmed that this mezcal strain was positive for flocculation in the presence of $\mathrm{Ca}^{2+}$ ions. Analysis of $F L O 1, F L O 5$ and $F L O 11$ gene expression implicated in flocculation in both Saccharomyces strains showed a strong transcriptional induction, mainly of the FLO5 gene in the mezcal Sc3Y8 strain.

Key words: Saccharomyces cerevisiae, flocculation, stress tolerance, fermentation, mezcal, agave must

\section{INTRODUCTION}

Mezcal production process presents fluctuating environmental conditions (i.e. osmotic pressure, ethanol concentration, $\mathrm{pH}$ and temperature conditions) which might be stressful for yeasts $(1,2)$. Particularly, mezcal must has a very different sugar composition from wine must. It is characterized by having a high concentration of fructose and low of glucose (up to 90 and approx. $10 \mathrm{~g} / \mathrm{L}$, respectively) $(3,4)$. Yeasts that participate in the fermentation process might display special features to survive these stressful conditions $(5,6)$ and according to their origin may be at different domestication stages (evolution events) (7). Phenotypic characterization has been widely documented in Saccharomyces wine strains (8-10), but only a few studies have reported these phenotypic traits in yeasts originating from mezcal must $(4,11)$. This is important since mezcal yeasts reported here are part of a different domestication event as compared to other well reported S. cerevisiae strains, and therefore their phenotypic characteristics may also vary (7). This has been corroborated by characterization of their osmotic and ethanol tolerance, and it has been observed that it depended on the type of hexose present in the medium, specifically fructose (11). Fructose consumption is also affected by temperature in Saccharomyces strains (12). Although, to our knowledge, there are no studies focused on exploring the effect of this stressor on Saccharomyces strains isolated from mezcal. 
It has been proposed that some stress-tolerant yeasts may flocculate (13) and exhibit good growth and survival in suboptimal environmental conditions $(14,15)$. Flocculation is a natural trait in S. cerevisiae and has been documented in brewer's and wine strains $(16,17)$. This asexual aggregation process is mediated by lectins (18) and is strain-dependent, or it may be triggered by different factors as nutrient depletion or alcohol accumulation (19-21). Temperature also affects the flocculation by acting at the level of cellular interactions (19). At molecular level, genes involved in this cellular aggregation have been identified, mainly those called FLO genes, which are classified according to their response to different environmental factors such as nutrients, $\mathrm{pH}$, ethanol and temperature changes $(1,22,23)$. In general, FLO1, FLO5 and FLO11 genes have been related to flocculation and cell aggregation in Saccharomyces strains $(10,24)$. Specifically in wine strains, FLO5 gene has recently been associated with the flocculation (25) and with cell wall organization and assembly (26).

Stress tolerance of yeasts, mainly under high fructose concentrations, is an important industrial trait since one of the primary problems of the alcoholic fermentation is the occurrence of stuck fermentation when glucose is depleted and the only fermentable sugar left is fructose (6). Therefore, the aim of this study is to add to the knowledge of the mechanisms involved in stress tolerance of yeasts adapted to high fructose concentrations. In order to do that, two physiologically related traits, flocculation and temperature stress tolerance, were characterized. For this reason, we analyzed a collection of $S$. cerevisiae strains isolated from mezcal must (4) looking for those yeasts tolerant to temperature stress (thermotolerant). Fermentative performance and potential of flocculation were determined in the strain that was the most tolerant to temperature. In addition, expression behaviour of important flocculation genes (FLO1, FLO5 and FLO11) under optimal and suboptimal temperature conditions was analyzed.

\section{MATERIALS AND METHODS}

\section{Yeast strains and culture conditions}

Six yeast strains belonging to our laboratory culture collection (Center for Genomic Biotechnology, National Polytechnic Institute, Reynosa, Mexico), obtained from fermenting mezcal must, were cultivated in yeast extract peptone dextrose (YPD) agar (containing in $\mathrm{g} / \mathrm{L}$ : yeast extract 10, casein peptone 20, agar 20 and glucose 20; Sigma-Aldrich, Merck, Monterrey, Mexico) (4). Yeasts were labelled as: LCBG-Sc3Y4, LCBG-Sc3Y3, LCBG-Sc3Y2, LCBG-Sc3D5, LCBG-Sc3Y5, LCBG-SC3Y8, and ScFerm (commercial wine strain S. cerevisiae Fermichamp, DSM Food Specialties B.V., Amsterdam, The Netherlands) that was used as control. Before each assay, a loop of each strain was pre-cultured in 250-mL Erlenmeyer flask with $50 \mathrm{~mL}$ of YPD broth (Sigma-Aldrich, Merck) for 18 h at $30^{\circ} \mathrm{C}$ and $200 \mathrm{rpm}$ in an incubator (Environ Shaker 3527; Lab-Line Instruments, Inc., Melrose Park, IL, USA).

\section{Selection of stress tolerant yeasts}

Two culture media were used on yeast extract peptone (YP) plates (in $\mathrm{g} / \mathrm{L}$ : yeast extract 10, casein peptone 20 and agar 20; Sigma-Aldrich, Merck) with $20 \mathrm{~g} / \mathrm{L}$ of either glucose (YPD) or fructose (YPF; both Sigma-Aldrich, Merck), to evaluate the influence of the carbon source on the stress tolerance of these yeasts. Selection of thermotolerant yeasts was conducted using a microdrop assay (11). The plates were incubated at $10,15,20,30$ and $40^{\circ} \mathrm{C}$, and colony forming units were counted every $24 \mathrm{~h}$ until there was a visible growth, varying from 24 up to $216 \mathrm{~h}$ at $10^{\circ} \mathrm{C}$. The strains that were able to grow in the whole temperature range in both hexoses were considered to be thermotolerant.

\section{Fermentation conditions}

Stress-tolerant yeasts were cultured in YP broth (in $\mathrm{g} / \mathrm{L}$ : yeast extract 10 and casein peptone 20; Sigma-Aldrich, Merck) supplemented with $100 \mathrm{~g} / \mathrm{L}$ of either glucose (YPD) or fructose (YPF; both Sigma-Aldrich, Merck). An inoculum concentration of $1.5 \cdot 10^{6} \mathrm{cell} / \mathrm{mL}$ was used for all the experiments, which were carried out in 50-mL Falcon tubes (Corning Inc., Corning, NY, USA) capped with cotton stoppers and maintained for $60 \mathrm{~h}$ without agitation at 30 or $40^{\circ} \mathrm{C}$. Cell population was determined by Neubauer chamber counting at different time intervals. Experiments were performed in triplicate.

\section{Metabolite quantification}

Residual reducing sugars in YPD or YPF broth were detected colorimetrically by a modified dinitrosalicylic acid (DNS) method (27) measuring the absorbance at $580 \mathrm{~nm}$ in a DU 650 spectrophotometer (Beckman Coulter, Brea, CA, USA). Calibration curves were prepared using glucose or fructose as standard (Sigma-Aldrich, Merck). Production of glycerol, acetic acid and ethanol was determined by HPLC analysis at different time intervals using an HO1200 HPLC equipment (Agilent Technologies, La Jolla, CA, USA) with an Aminex HPX-87 column with a flow of $0.5 \mathrm{~mL} / \mathrm{min}$ and a mobile phase of $\mathrm{H}_{2} \mathrm{SO}_{4}(5 \mathrm{mM})$ in Milli-Q water (Millipore, Burlington, MA, USA) for $30 \mathrm{~min}$, and coupled to a refractive index (RI) detector. The samples were centrifuged at $14400 \mathrm{xg}$ for $5 \mathrm{~min}$ at $10^{\circ} \mathrm{C}$ in a Spectrafuge $24 \mathrm{D}$ (Labnet International Inc., Edison, $\mathrm{NJ}, \mathrm{USA})$, then diluted $(1: 10, V / V)$ in the mobile phase and filtered through nylon membranes (pore size $0.45 \mu \mathrm{m}, 47 \mathrm{~mm}$, GVS Magna $^{\mathrm{TM}}$; Thermo Scientific, Mexico City, Mexico). Calibration curves within ranges of 0-20 (ethanol), 0-10 (glycerol) and 0-10 g/L (acetic acid) were set up for commercial standards (Sigma-Aldrich, Merck). Finally, experiments were performed in triplicate.

\section{Construction of standard cell curve}

Cell number was determined spectrophotometrically using a standard curve constructed with correlation of the absorbance measured at $600 \mathrm{~nm}$ (DU 650 spectrophotometer; 
Beckman Coulter) and the number of cells of each strain present in a Neubauer chamber. Each experiment was performed in triplicate. Linear regressions and their fitting were: $y=2 \cdot 10^{7} x$, with $R^{2}=0.9961$, and $2 \cdot 10^{7} x$ with $R^{2}=0.954$ for ScFerm and $\mathrm{Sc} 3 \mathrm{Y} 8$, respectively.

\section{Flocculation analysis}

Flocculation was determined using the microflocculation method (21). Total cell number was calculated by extrapolation of the absorbance values obtained in each standard cell curve, and the number of flocculent cells was calculated by subtracting the number of cells that remained in the suspension after stopping the agitation, according to Ogata (28). As a negative flocculent control, the assay was conducted using deionized water instead of EDTA solution (Sigma-Aldrich, Merck). Experiments were performed in triplicate.

\section{Confocal microscopy}

Flocculation was analyzed by confocal microscopy. Briefly, selected flocculent and non-flocculent strains were grown at 30 and $40{ }^{\circ} \mathrm{C}$ as described above. ScFerm was selected as the non-flocculent yeast. Cells were resuspended in citrate buffer $\left(50 \mathrm{mM}, \mathrm{pH}=4.0\right.$; containing $8 \mathrm{mM} \mathrm{CaCl}_{2}$; Sigma-Aldrich, Merck) and then $0.4 \%(\mathrm{~m} / \mathrm{V})$ Solophenyl Flavine 7GFE 500 (AK Scientific, Inc., Union City, CA, USA) was added. Incubation was conducted at room temperature in darkness. The samples were washed with citrate buffer. Images were visualized and acquired with a confocal microscopy TCS SP5 $X$ (Leica Microsystems, New York, NY, USA) at magnifications $20 \times$ and $40 \times$ with and without 4.0 digital zoom (confocal microscopy software LAS X v. 2.0.2.14392; Leica Microsystems) at 490 and $510-550 \mathrm{~nm}$ for excitation and emission, respectively. Finally, deionized water instead of the citrate buffer served as a negative flocculent control.

\section{FLO1, FLO5 and FLO11 primer design and validation}

Genomic DNA isolation was conducted in S. cerevisiae (Sc3Y8 and ScFerm) cells grown in YPD broth using the DNAzol kit (Molecular Research Center, Cincinnati, OH, USA). DNA amount and quality were determined by using NANODROP 2000 equipment (Thermo Scientific). DNA samples were adjusted at final concentration of $100 \mathrm{ng} / \mu \mathrm{L}$. For real-time polymerase chain reaction (PCR) amplification of FLO1 and FLO11 genes, the following primer sets were used: FLO1-F 5'-ATGCCTCATCGCTATATGTTTTTG-3' and FLO1-R 5'-GCTCCTGAGGCCACACTAGTTAG-3, and FLO11-F 5'-CCTCCGAAGGAACTAGCTGTAATT-3' and FLO11-R 5'-AGTCACATCCAAAGTATACTGCATGAT-3', which produce fragments of 68 and 103 bp, respectively (23). To amplify the $F L O 5$ gene, a primer set was preliminarily designed for this study (FLO5-F 5'-ATGACAATTGCACACCACTGC-3' and FLO5-R 5'-ATATATGCTGCATTCGAATATGTGG-3') from S. cerevisiae S288c (NM_001179342.1) sequence. Then, using this FLO5 sequence, a new primer set was designed
(FLO5-F2 5'-GCATCAGGAAGTACGGAAGTCA-3' and FLO5-R2 5'-TGCTGCATTCGAATATGTGGA-3'), which corresponds to a 110-bp fragment. MEGA v. 4.1 (29) program was used to align and design these primer sets. PCR products were amplified in reaction mix that contained $2 \mu \mathrm{L} \mathrm{MgCl}_{2}(50 \mathrm{mM}$; Bioline, Taunton, MA, USA), $2 \mu \mathrm{L}$ dNTP mix (100 mM; Bioline), $2.5 \mu \mathrm{L}$ PCR buffer (Bioline), $1.5 \mu \mathrm{L}$ each primer (50 ng), $0.2 \mathrm{U}$ Taq polymerase (Bioline), and $3 \mu \mathrm{L}$ DNA template (100 ng). Initial denaturalization time was 5 min at $94^{\circ} \mathrm{C}$, followed by 35 cycles of 1 min at $94^{\circ} \mathrm{C}$, $1 \mathrm{~min}$ at $61^{\circ} \mathrm{C}$ and $1 \mathrm{~min}$ at $72^{\circ} \mathrm{C}$, with a final extension cycle of $10 \mathrm{~min}$ at $72^{\circ} \mathrm{C}$. PCR products were verified and purified from an agarose gel (1 \%) using Wizard SV gel and PCR clean-up kit (Promega, Madison, WI, USA). These PCR products were then bound and cloned in a pGEM-T vector (Promega) and transformed using Escherichia coli DH10B competent cells (Invitrogen, Carlsbad, CA, USA). FLO1, FLO5 and FLO11 gene identity was confirmed by sequencing with an $\mathrm{ABI} 377$ DNA sequencer equipment (Applied Biosystems, Foster City, CA, USA) with universal M13 primers and the BigDye terminator v. 3.1 cycle sequencing kit (Applied Biosystems).

\section{Gene expression analysis}

Expression of the FLO1, FLO5 and FLO11 genes was determined on selected (Sc3Y8 and ScFerm) strains grown on YPD broth at 30 and $40^{\circ} \mathrm{C}$. Cells were collected after 12, 24, 48,60 and $72 \mathrm{~h}$. RNA isolation was carried out using the TRI reagent kit (Molecular Research Center) according to manufacturer's instructions. RNA (1 $\mu \mathrm{g})$ was treated with $1 \mathrm{U}$ RQ1 RNase-Free DNase I (Promega), adjusting the volume to 10 $\mu \mathrm{L}$, and incubated for $30 \mathrm{~min}$ at $37^{\circ} \mathrm{C}$. Reaction was stopped by adding $1 \mu \mathrm{L}$ RQ1 DNase Stop Solution (Promega) followed by an incubation for $10 \mathrm{~min}$ at $65^{\circ} \mathrm{C}$. Genomic DNA contamination was verified by using agarose gels at $1.3 \%$ and by PCR reaction as follows: RNA treated with DNase was used as negative amplification template for the UBC6 gene. This encodes a constitutive ligase El protein involved in the ubiquitin-protein degradation (30). Genomic DNA was used as positive amplification control with the primers (UBC6-F 5'-GATACTTGGAATCCTGGCTGGTCTGTCTC-3' and UBC6-R 5'-AAAGGGTCTTCTGTTTCATCACCTGTATTTGC-3'). PCR products were amplified in a $25-\mu \mathrm{L}$ reaction containing $2 \mu \mathrm{L} \mathrm{MgCl}_{2}(50 \mathrm{mM}$; Bioline), $2 \mu \mathrm{L}$ dNTP mix (100 mM; Bioline), $2.5 \mu \mathrm{L}$ PCR buffer (Bioline), $1.5 \mu \mathrm{L}$ each primer (50 ng), $0.3 \mu \mathrm{L}$ Taq polymerase (Bioline), and $3 \mu \mathrm{L}$ genomic DNA template (100 ng) or RNA treated with DNase $(50 \mathrm{ng})$. Initial denaturalization time was 5 min at $94^{\circ} \mathrm{C}$, followed by 35 cycles at $94^{\circ} \mathrm{C}$ for $1 \mathrm{~min}, 1 \mathrm{~min}$ at $59^{\circ} \mathrm{C}$ and $1 \mathrm{~min}$ at $72{ }^{\circ} \mathrm{C}$, with a final extension cycle at 72 ${ }^{\circ} \mathrm{C}$ for 10 min. CDNA synthesis was carried out using $1 \mu \mathrm{g}$ RNA and the GoScript ${ }^{\mathrm{TM}}$ Reverse Transcription System (Promega). Briefly, a final reaction volume of $20 \mu \mathrm{L}$ containing $1 \mu \mathrm{g}$ of DNase I-treated RNA was mixed with $0.5 \mu \mathrm{g}$ Oligo(dT)15 and random primers. Then, the reaction was incubated at $70{ }^{\circ} \mathrm{C}$ for 5 min, chilled in ice, and an RT Master Mix containing GoScript $^{\mathrm{TM}} 1 \times$ reaction buffer, $5 \mathrm{mM} \mathrm{MgCl}, 0.5 \mathrm{mM}$ each dNTP, $1 \mathrm{U}$ Recombinant RNasin Ribonuclease Inhibitor and $15 \mathrm{U} /$ 
$\mu \mathrm{g} \mathrm{GoScript}{ }^{\mathrm{TM}}$ Reverse Transcriptase was added. Reaction was incubated at $25^{\circ} \mathrm{C}$ for $5 \mathrm{~min}$, then at $37^{\circ} \mathrm{C}$ for $1 \mathrm{~h}$, and finally at $70^{\circ} \mathrm{C}$ for $15 \mathrm{~min}$. A kanamycin-positive control of RNA provided in the kit was used to estimate the yield of CDNA synthesis. CDNA amount was verified in a NANODROP equipment (NANODROP-1000; Thermo Scientific) and kept at -60 ${ }^{\circ} \mathrm{C}$ until its use.

Expression of $F L O$ genes was determined by the $\triangle \triangle C q$ method (31) using UBC6 gene as a reference (30). Amplification was standardized in a real-time thermal cycler (GeneAmp PCR-System 9700; Applied Biosystems). Briefly, $50 \mathrm{ng} / \mu \mathrm{L}$ cDNA were used as template in $20 \mu \mathrm{L} P C R$ reaction mix containing $10 \mu \mathrm{L}$ PCR Master Mix (2X; Bioline) with SYBR Green (Applied Biosystems), and 0.5 pmol of each forward and reverse primer set. Conditions of amplification were similar to the previous section. In addition, negative control for each gene was included. Fluorescent signal of SYBR Green was standardized using the ROX dye included in the SYBR Green PCR Master Mix (Applied Biosystems).

\section{Data analysis}

Gene relative expression (R) was calculated using the following equation:

$$
\mathrm{R}=\left(\mathrm{E}_{\text {Ref }}\right) \mathrm{C}_{\text {tRef }} /\left(\mathrm{E}_{\text {Target }}\right) \mathrm{C}_{\text {tTarget }}
$$

where $E_{\text {Ref }}$ and $E_{\text {Target }}$ are the efficiencies of the reference and target gene, respectively, and $C_{\text {tRef }}$ and $C_{\text {tTarget }}$ are the threshold cycle $\left(C_{t}\right)$ average values of the reference and target gene, respectively $(31)$. Significant differences $(p<0.05)$ among the mean values were determined by Tukey's test using one-way ANOVA and StatSoft Statistica software, v. 8.0 (32).

\section{RESULTS AND DISCUSSION}

\section{Selection of thermotolerant strain}

The analysis of yeast growth at different temperatures $\left(10,15,20,30\right.$ or $\left.40^{\circ} \mathrm{C}\right)$ showed that the carbon source affected the growth behaviour since all the Saccharomyces strains grew on fructose at all the temperatures (Table 1), but only Sc3Y 8 strain was able to grow on glucose at $10^{\circ} \mathrm{C}$. De la
Torre-González et al. (11) reported that this Sc3Y8 strain was able to grow at concentrations of fructose up to $850 \mathrm{~g} / \mathrm{L}$ at 29 ${ }^{\circ} \mathrm{C}$, and in an ethanol shock test, it was able to survive at 25 $\%$ ethanol (4). Previously, it had been documented that lower temperatures affect the fructose consumption in Saccharomyces strains (12) and that this sugar may also decrease the osmotic pressure and ethanol stress tolerance level in Saccharomyces and non-Saccharomyces strains (11). The differences in stress tolerance that these strains show are in concordance with the theory of stress cross-response (15). Finally, the Sc3Y8 strain was selected for further studies because of its thermotolerance in the two sugar sources analyzed.

\section{Fermentation profiles}

The flocculation capability of the most thermotolerant mezcal strain, Sc3Y8, was further analyzed and compared to an industrial wine strain (ScFem), which is known to ferment grape must sugars to dryness (33). Both selected strains were analyzed in cultures with glucose or fructose $(100 \mathrm{~g} / \mathrm{L})$, with the aim of comparing the fermentation yields under optimal (30 ${ }^{\circ} \mathrm{C}$ ) and suboptimal $\left(40^{\circ} \mathrm{C}\right)$ temperature conditions. In general, all analyzed strains at $30^{\circ} \mathrm{C}$ showed an exponential growth up to $24 \mathrm{~h}$ and entered the stationary phase at $60 \mathrm{~h}$ (Fig. 1). Interestingly, Sc3Y8 strain, which exhibited a wide thermotolerance in solid culture, showed the lowest growth under these conditions. At $40{ }^{\circ} \mathrm{C}$, both Saccharomyces strains had a lower growth than at $30^{\circ} \mathrm{C}$. Regarding sugar consumption, these strains show different profiles since only the ScFerm completely consumed both sugars at $30^{\circ} \mathrm{C}$ (after $30 \mathrm{~h}$ ), but left 50 and 23 $\mathrm{g} / \mathrm{L}$ of glucose and fructose, respectively, at $40{ }^{\circ} \mathrm{C}$. The Sc3Y8 strain had a high residual sugar concentration of 17 and $31 \mathrm{~g} / \mathrm{L}$ of glucose and fructose, respectively, at $30^{\circ} \mathrm{C}$, and overall it was less efficient than the industrial strain at this temperature. At 40 ${ }^{\circ} \mathrm{C}$ the residual sugar concentration was similar to the one of ScFerm. Different fructose uptake at different temperatures has been previously reported by Dumont (12), who tested five industrial wine yeast. Fructose and glucose consumption capacity by these industrial strains at increased temperatures was analyzed, with and without nitrogen limitation, and it was observed that glucose was consumed at higher rate at the beginning of the fermentation and fructose at a slower steady

Table 1. Colony counts obtained by using the microdrop assay in yeast extract peptone dextrose (YPD) or yeast extract fructose (YPF) plates at different temperatures

\begin{tabular}{|c|c|c|c|c|c|c|c|c|c|c|}
\hline \multirow{4}{*}{$\begin{array}{l}\text { Saccharomyces } \\
\text { strain }\end{array}$} & \multicolumn{10}{|c|}{$N($ colony $) /\left(C F U \cdot 10^{6} / \mathrm{mL}\right)$} \\
\hline & \multicolumn{5}{|c|}{ YPD plate } & \multicolumn{5}{|c|}{ YPF plate } \\
\hline & \multicolumn{10}{|c|}{ Temperature $/{ }^{\circ} \mathrm{C}$} \\
\hline & 10 & 15 & 20 & 30 & 40 & 10 & 15 & 20 & 30 & 40 \\
\hline ScFerm & 0 & $1.3 \pm 0.2$ & $1.5 \pm 0.4$ & $2.1 \pm 0.8$ & $1.5 \pm 0.2$ & $1.5 \pm 0.4$ & $1.2 \pm 0.1$ & $1.8 \pm 0.1$ & $2.3 \pm 0.3$ & $1.3 \pm 0.4$ \\
\hline Sc3Y8 & $2.6 \pm 0.3$ & $2.5 \pm 0.3$ & $4.8 \pm 0.3$ & $3.9 \pm 1.3$ & $2.3 \pm 0.2$ & $3.8 \pm 0.5$ & $2.4 \pm 0.5$ & $4.6 \pm 0.1$ & $4.5 \pm 0.3$ & $2.5 \pm 0.5$ \\
\hline Sc3Y5 & 0 & $1.9 \pm 0.2$ & $2.2 \pm 0.4$ & $2.0 \pm 0.6$ & $2.4 \pm 0.3$ & $3.3 \pm 0.4$ & $1.9 \pm 0.2$ & $3.2 \pm 0.3$ & $4.0 \pm 1.0$ & $2.2 \pm 0.6$ \\
\hline Sc3D5 & 0 & $2.7 \pm 0.3$ & $3.3 \pm 0.2$ & $2.9 \pm 0.1$ & $3.4 \pm 0.4$ & $2.7 \pm 1.1$ & $3.0 \pm 0.4$ & $2.9 \pm 0.9$ & $2.4 \pm 0.2$ & $2.8 \pm 0.6$ \\
\hline Sc3Y2 & 0 & $6.5 \pm 0.4$ & $7.0 \pm 1.4$ & $11.4 \pm 0.7$ & $8.1 \pm 1.6$ & $7.5 \pm 0.8$ & $6.0 \pm 0.9$ & $6.7 \pm 1.1$ & $11.4 \pm 0.6$ & $7.4 \pm 0.3$ \\
\hline $\mathrm{Sc} 3 \mathrm{YY} 3$ & 0 & $1.8 \pm 0.5$ & $3.1 \pm 0.5$ & $2.5 \pm 0.3$ & $2.0 \pm 0.5$ & $3.8 \pm 1.2$ & $2.0 \pm 0.2$ & $3.3 \pm 0.3$ & $3.2 \pm 0.2$ & $2.0 \pm 0.4$ \\
\hline Sc3Y4 & 0 & $1.8 \pm 0.3$ & $2.4 \pm 0.3$ & $3.4 \pm 0.7$ & $2.5 \pm 0.7$ & $2.9 \pm 0.6$ & $2.7 \pm 0.8$ & $2.6 \pm 0.5$ & $4.0 \pm 0.2$ & $1.7 \pm 0.1$ \\
\hline
\end{tabular}



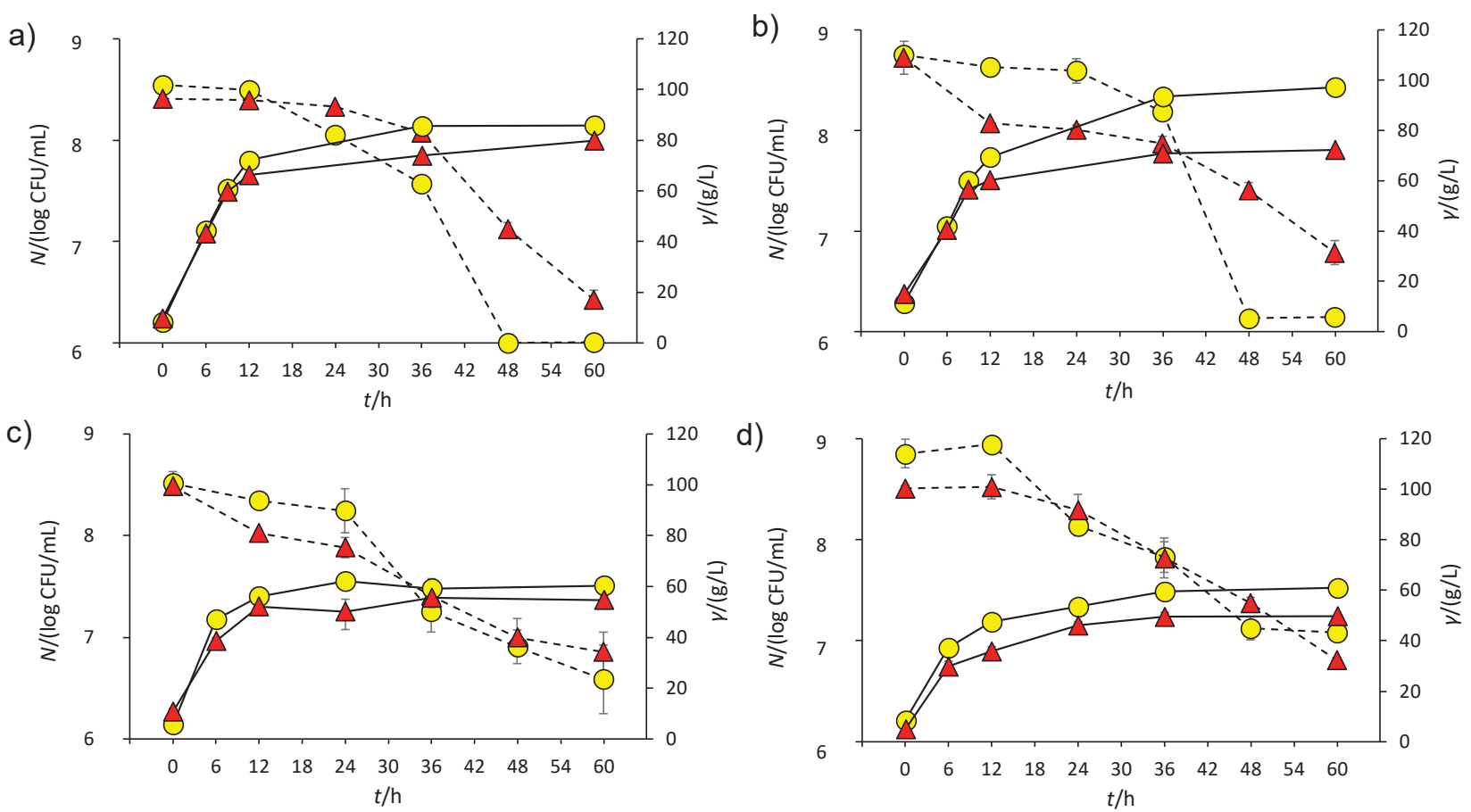

Fig. 1. Cell counts and sugar consumption of Saccharomyces cerevisiae Sc3Y8 (red triangles) and ScFerm (yellow circles) strains grown in yeast extract peptone dextrose and fructose (YPD and YPF) broths at 30 ( $a$ and b, respectively) and $40{ }^{\circ} \mathrm{C}$ ( $\mathrm{c}$ and d, respectively). Solid and dotted lines indicate the sugar consumption and cell count, respectively

rate. Similar results were reported in some mezcal yeasts (4), including the Sc3Y8 selected in this study. Additionally, Dumont et al. (12) observed that at the latter stage of fermentation, the industrial wine yeasts that are considered fructophilic are able to continue uptaking fructose while leaving a higher residual glucose concentration in the medium. The same authors documented that the higher the temperature, the better the fructose consumption by all except one of the tested strains (a low temperature specialist, as stated by the authors), and it is worth noticing that their higher temperature $\left(28^{\circ} \mathrm{C}\right)$ tested is similar to the optimal $\left(30^{\circ} \mathrm{C}\right)$ temperature used in our study. Hence, the results shown in this work concerning an enhanced fructose consumption capacity at high temperatures are indeed one of the most interesting phenotypical characteristics of this mezcal strain. It is clear that more effort must be made to clarify this different kinetic behaviour in relation to fructose in this strain.

Concerning the production of metabolites, at the end of cultivation (60 h), glycerol, ethanol and acetic acid concentrations increased in all selected strains when grown on fructose at $40^{\circ} \mathrm{C}$ (Table 2). Sc3Y8 strain showed higher metabolic accumulation at this temperature. These different fermentation profiles as a consequence of the increase in the temperature and the type of used sugar could be due to their different ethanol tolerance and their differences in the hexose transporter efficiencies $(15,33)$. Interestingly, glycerol was the metabolite with the higher increase ( $>7$ times) at 40 than at $30^{\circ} \mathrm{C}$ (Table 2). It has been reported that temperature affects the glycerol accumulation in
S. cerevisiae strains (8) since it acts as an osmoregulator between the cytosol and the environment (34). Similar to the accumulation of glycerol, the alcohol and acetic acid levels also increased ( 2 to 3 times) when these selected strains were grown at $40^{\circ} \mathrm{C}$ using fructose as a carbon source, particularly Sc3Y8 strain. In general, the use of fructose at $40{ }^{\circ} \mathrm{C}$ increased the metabolite production by the yeasts, similar to what had been previously reported for some industrial S. cerevisiae strains (12). It is worth noticing that under stressful (temperature, osmotic pressure, etc.) conditions, Saccharomyces strains tend to overproduce glycerol and acetic acid, and to produce less biomass, as corroborated with the colony count in Table 1, i.e. the number of viable cells that grew in glucose or fructose at the two highest temperatures tested for all the strains. This general trend can be observed for both hexoses when comparing metabolite profiles (Table 2 ) at 30 and $40^{\circ} \mathrm{C}$. These results suggest that the two analyzed strains have a different metabolic response at $40^{\circ} \mathrm{C}$, with the mezcal yeast ( $\mathrm{Sc} 3 \mathrm{Y} 8$ ) producing more ethanol at this temperature, probably due to its original niche of isolation, which is a fermentation that is carried out at high fructose concentration and uncontrolled temperature.

\section{Flocculation ability}

Flocculation has been determined in some yeast species, mainly in S. cerevisiae, as a mechanism to overcome stress conditions (i.e. alcoholic or nutrient depletion) $(22,35)$. It was observed only in Sc3Y8 strain (Fig. 2). This phenomenon was 
Table 2. Concentration of metabolites in selected strains after $60 \mathrm{~h}$ of fermentation under different temperature conditions

\begin{tabular}{|c|c|c|c|c|c|c|}
\hline \multirow{2}{*}{ Saccharomyces strain } & \multirow{2}{*}{ Temperature $/{ }^{\circ} \mathrm{C}$} & \multirow{2}{*}{ Carbon source } & \multicolumn{4}{|c|}{$\gamma /(\mathrm{g} / \mathrm{L})$} \\
\hline & & & Glycerol & Ethanol & Acetic acid & Residual sugar \\
\hline \multirow{4}{*}{ ScFerm } & \multirow{2}{*}{30} & Glucose & $1.0 \pm 0.2$ & $15.5 \pm 1.2$ & $2.2 \pm 0.4$ & $0.19 \pm 0.1$ \\
\hline & & Fructose & $1.1 \pm 0.2$ & $14.3 \pm 1$ & $1.8 \pm 0.3$ & $5.8 \pm 0.3$ \\
\hline & \multirow{2}{*}{40} & Glucose & $5.4 \pm 0.1$ & $26.8 \pm 3.4$ & $4.5 \pm 1.5$ & $23.4 \pm 13.5$ \\
\hline & & Fructose & $8.0 \pm 0.1$ & $32.6 \pm 1.7$ & $6.4 \pm 0.1$ & $43.2 \pm 3.1$ \\
\hline \multirow{4}{*}{ Sc3Y8 } & \multirow{2}{*}{30} & Glucose & $0.8 \pm 0.0$ & $12.5 \pm 1.1$ & $1.7 \pm 0.4$ & $17.1 \pm 3.6$ \\
\hline & & Fructose & $1.5 \pm 0.3$ & $15.1 \pm 1.5$ & $2.1 \pm 0.4$ & $31.4 \pm 4.8$ \\
\hline & \multirow{2}{*}{40} & Glucose & $3.6 \pm 2.7$ & $33.3 \pm 3$ & $2.1 \pm 0.2$ & $34.2 \pm 7.8$ \\
\hline & & Fructose & $8.6 \pm 0.4$ & $43.6 \pm 3.3$ & $7.3 \pm 0.5$ & $32.3 \pm 0.2$ \\
\hline
\end{tabular}

$\mathrm{CaCl}_{2}$-dependent since it was not observed in the presence of water or buffer without calcium (data not shown). Confocal microscopy analysis of Sc3Y8 strain using the fluorophore Solophenyl Flavine 7GFE 500 (AK Scientific, Inc.) allowed to assess some changes in the cell wall conformation at $40^{\circ} \mathrm{C}$, similarly to the observations made by Soares (19), using the fluorophore Calcofluor White M2R in cells that were subject to osmotic stress $(1 \mathrm{~mol} / \mathrm{L} \mathrm{NaCl})$ or a brief heat-shock $\left(52{ }^{\circ} \mathrm{C}\right.$ for $5 \mathrm{~min})$. In this study, the temperature stress was maintained during fermentation. The fluorophore Solophenyl Flavine 7GFE 500 has not been previously used in flocculation analysis so it was first tested to determine its incubation time, concentration and viable cell number. The fluorophore did not show adverse effects on the cell viability during or after flocculation assay, so it was suitable for cell observations. It was determined that the best mass per volume ratio of Solophenyl Flavine was $0.4 \%$ at an incubation time of $15 \mathrm{~min}$. Observations at $30^{\circ} \mathrm{C}$ in the absence of $\mathrm{CaCl}_{2}$ evidenced oval structures with a higher fluorescent intensity, likely the scars generated during budding (Fig. 3). In contrast, at $40^{\circ} \mathrm{C}$, the fluorophore recognized the whole cell wall and also allowed to observe cell lysis (Fig 3a). To confirm that the fluorescence detected at $40{ }^{\circ} \mathrm{C}$ is a consequence of the cell wall recognition by the Solophenyl Flavine and not their inclusion in the

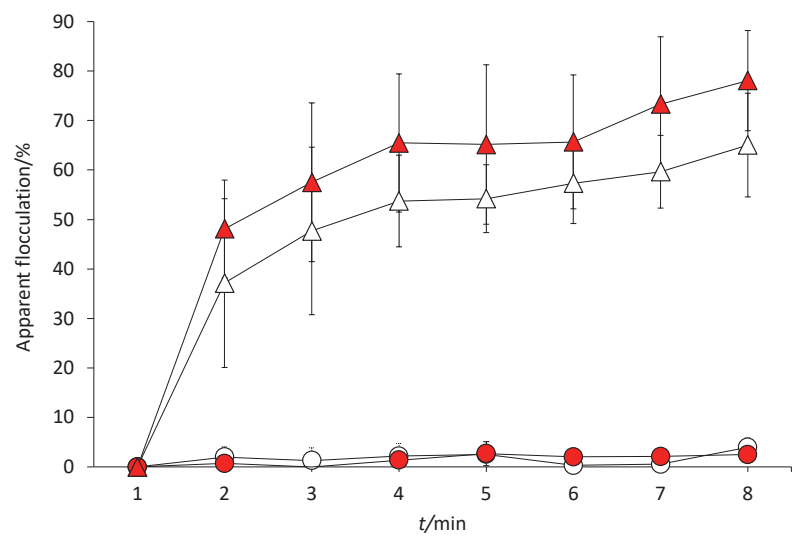

Fig. 2. Flocculation phenomenon in the presence of $\mathrm{CaCl}_{2}$ in the selected Saccharomyces cerevisiae Sc3Y8 (triangles) and ScFerm (circles) strains. White and red symbols indicate the fermentation temperature of 30 and $40^{\circ} \mathrm{C}$, respectively lysed cells, a viability assay was conducted in parallel. Fig. $3 \mathrm{~b}$ and Fig. 3c compare the fluorescent analysis and the viability determination (plate count). In general, a reduction in the viability at $40{ }^{\circ} \mathrm{C}$ was observed although Sc3Y8 strain was slightly more viable than ScFerm (non-flocculent strain used as a control). Regarding fluorescent analysis, similar behaviour was observed between both $S$. cerevisiae strains at $30^{\circ} \mathrm{C}$, but these values increased significantly in the ScFerm strain at $40^{\circ} \mathrm{C}$. Considering the results at $40^{\circ} \mathrm{C}$, the increase in the fluorescence might be a consequence of the reduction in the viability and of the cellular lysis detected in the ScFerm strain, in contrast to the more temperature-tolerant Sc3Y8 strain, which exhibited a lower reduction of their fluorescence even at $40^{\circ} \mathrm{C}$.

Confocal microscopy analysis using the Solophenyl Flavine in the presence of $\mathrm{CaCl}_{2}$ showed cell aggregates only in the Sc3Y8 strain. These cell aggregates showed apparent different sizes depending on the temperature conditions (data not shown). Finally, at $40{ }^{\circ} \mathrm{C}$, less lysed cells were observed in the Sc3Y8 than in ScFerm strain, supporting the previous viability assay. These results suggested that the flocculation phenotype in the Sc3Y8 strain may contribute to its thermotolerance due to the changes in the cell wall conformation and integrity, allowing a higher viability. Also, it has been reported that temperature affects the flocculation phenomenon at the level of cellular interactions, probably as a consequence of the flocculin denaturalization (19). Flocculation observed in Sc3Y8 cells slightly increased when the temperature was raised from 30 to $40^{\circ} \mathrm{C}$, although it was not statistically significant. Additionally, the floccule size in the Sc3Y8 strain is apparently bigger at 40 than at $30^{\circ} \mathrm{C}$. It has been reported that small changes in the cell wall hydrophobicity can also affect the floccule size (22). The differences found in the staining pattern caused by the fluorophore Solophenyl Flavine are not directly correlated with the cell viability (36). Nevertheless, it seems to be related to changes in the cell envelope caused by the increase of temperature. Recently, a transcriptomic relationship between the stress response and the flocculation was identified in a wine S. cerevisiae (F6789A) strain after deletion of the FLO5 gene. These genes regulate stress tolerance and are related with cell wall reorganization and adhesion (26). 
a)
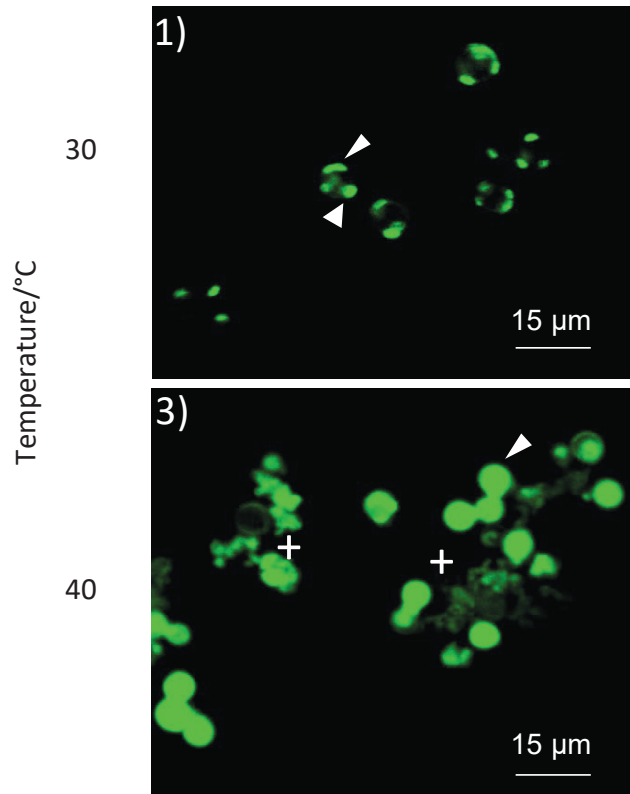

b)

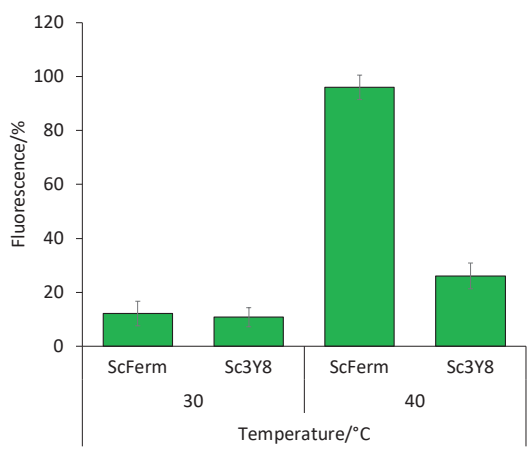

Sc3Y8
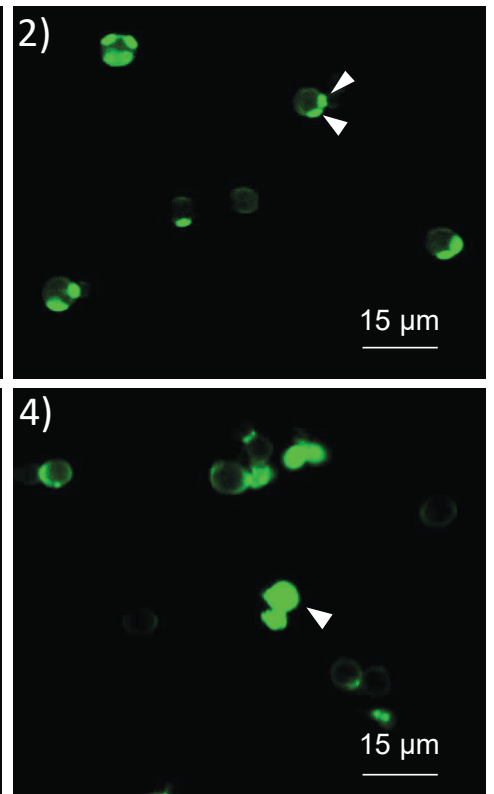

c)

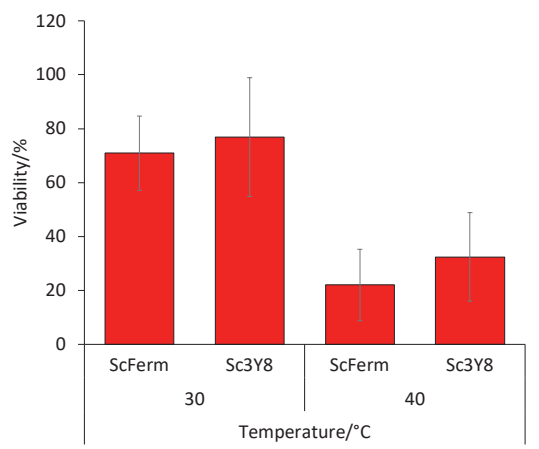

Fig. 3. Fluorescence analysis using Solophenyl Flavine: a) Solophenyl Flavine fluorescence in ScFerm (1 and 3) and Saccharomyces cerevisiae Sc3Y8 ( 2 and 4) cells grown at 30 ( 1 and 2$)$ and at $40{ }^{\circ} \mathrm{C}(3$ and 4$)$ on deionized water without $\mathrm{CaCl}_{2}$. Arrows on cells grown at $30^{\circ} \mathrm{C}$ show the sites that probably correspond to bud scars, and on cells grown at $40^{\circ} \mathrm{C}$ where the signal covers all cell surface area. The crosses show the cell lysis at $40^{\circ} \mathrm{C}$. Relative percentages of: b) fluorescence and c) viability during flocculation assay at different temperatures $\left(30\right.$ and $\left.40^{\circ} \mathrm{C}\right)$. Relative fluorescence was calculated on the basis of stained cells compared to the total cell number in 12 microscopic fields. Relative viability was expressed as CFU count in the microdrop assay using the initial inoculum of $5 \cdot 10^{7} \mathrm{cell} / \mathrm{mL}$. Experiments were done in triplicate

\section{FLO gene expression at 30 and $40^{\circ} \mathrm{C}$}

With the aim to better understand the flocculation phenomenon in the Sc3Y8 strain, a FLO gene expression analysis was conducted. Genetic regulation, specifically involving lectins, has been related to physiological and epigenetic changes that in turn might be involved in cell wall synthesis (15). Gene fragments of the selected FLO1, FLO5 and FLO11 genes were successfully amplified generating sequence fragments of 68 , 193 and 103 bp, respectively (Table S1). FLO1, FLO5 and FLO11 transcript accumulation was analyzed in these Saccharomyces strains on YPD broth at 30 and $40^{\circ} \mathrm{C}$. Results showed that FLO1 gene transcripts were constant at $30^{\circ} \mathrm{C}$ in both Saccharomyces strains. However, at $40^{\circ} \mathrm{C}$ a slight but significant (Tukey's test; $\mathrm{p}<0.05)$ induction $(6 \%)$ was observed after $12 \mathrm{~h}$, particularly in the Sc3Y8 strain. ScFerm also exhibited a reduced induction
(3.8\%) at $60 \mathrm{~h}$ of culture (Fig. 4). A stronger FLO5 expression in Sc3Y8 strain was induced at 40 (up to 20 -fold) than at 30 ${ }^{\circ} \mathrm{C}$. This transcript induction was statistically different among strains after $12 \mathrm{~h}$, and had a maximal value of $175 \%$ at $48 \mathrm{~h}$ in the Sc3Y8 strain, which coincides with the beginning of the stationary phase (Fig. 1). The non-flocculent strain (ScFerm) kept constant its FLO5 gene expression at both temperatures.

Our results for the flocculent Sc3Y8 strain suggest a transcriptional induction, at least of FLO1 and FLO5 genes, as a consequence of the temperature increase. Expression of both genes was constant in non-flocculent strain ScFerm, with only a slight increase at $40^{\circ} \mathrm{C}$. FLO5 gene transcription in Sc3Y8 strain strongly increased at both temperatures, but it was the highest at $40^{\circ} \mathrm{C}$. Di Gianvito et al. (26) have recently demonstrated the importance of the FLO5 gene during flocculation and related it to stressful (ethanol at $20 \%$ ) conditions in 

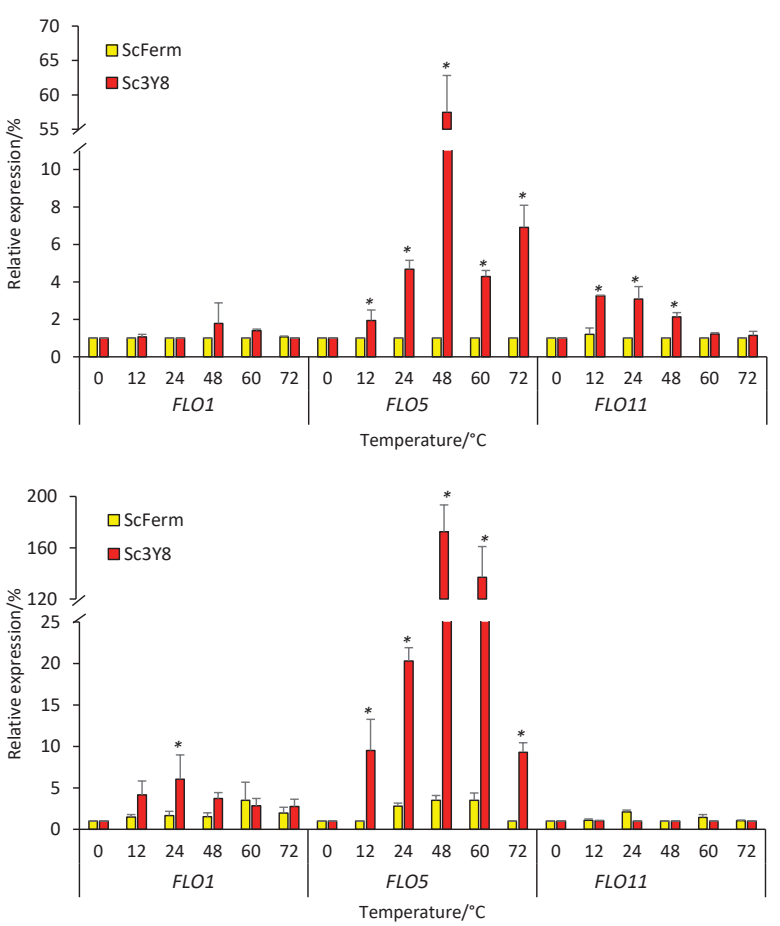

Fig. 4. Relative expression of FLO1, FLO5 and FLO11 genes in ScFerm (yellow) and Saccharomyces cerevisiae Sc3Y8 (red) strains grown for $72 \mathrm{~h}$ in yeast extract peptone dextrose (YPD) broth (100 g/L) at: a) $30{ }^{\circ} \mathrm{C}$ or b) $40{ }^{\circ} \mathrm{C}$, determined by RT-qPCR. Genetic expression was normalized using the constitutive UBC6 gene. All the analyses were performed with three biological replicates from at least two independent experiments. Error bars represent the standard error $(N=3)$. Values with asterisks are significantly different according to the Tukey's test $(\mathrm{p}<0.05)$

different Saccharomyces wine strains (10). Recently, this gene has been deleted in a S. cerevisiae wine strain (F6789A- $\Delta$ flo5) causing an up-regulation of genes related to assembly, shape and cell adhesion, and genes related to the organization of the cell wall, among others (26). The transcription of FLO1 gene has also been related to flocculation ability in Saccharomyces strains, although with a lower transcriptional activation of FLO5 gene (10), in line with our observations. The predictive protein products of FLO1 and FLO5 are $96 \%$ similar and both are subtelomeric genes but they are not alleles (37). The regulated expression of these FLO1 and FLO5 genes leads to specific phenotype intensities, resulting in cell aggregation, cell surface properties, and flocculation $(10,23)$. Finally, the expression profile of the $\mathrm{FLO} 11$ gene showed that at $30^{\circ} \mathrm{C}$, there was a slightly higher statistically significant difference in strain Sc3Y8 at 24 and $48 \mathrm{~h}$ (increase in expression of 2 and $3.2 \%$, respectively). At $40^{\circ} \mathrm{C}$, there was a constantly low expression of FLO11 in both strains. This gene has been related to a wide phenotype variety, such as flocculation, the invasive growth and flor formation (38), probably depending on the culture conditions. Further studies using other cell aggregation or cell-surface adherence genes as AMN1 and FLO8 must be conducted to clarify the relation between the flocculation and the stress response, specifically when these cell properties are involved (39).

\section{CONCLUSIONS}

Saccharomyces cerevisiae Sc3Y8 mezcal strain increased its metabolite accumulation at $40^{\circ} \mathrm{C}$ in the presence of fructose as a sole carbon source, as compared to the control strain. This mezcal strain was also able to flocculate in the presence of calcium ions. Gene expression analysis of the flocculation-related genes FLO1, FLO5 and FLO11 showed that the Sc3Y8 strain has a different gene expression profile from the non-flocculant commercial wine strain S. cerevisiae Fermichamp (ScFerm) industrial strain. Flocculation seems to be associated with morphological cell wall changes that might contribute to its thermotolerant phenotype and to a higher viability, which in turn allows a better fermentation productivity at high temperature. Nonetheless, to corroborate this relation, the construction of $\mathrm{F} L O$-specific mutants is required to address their exact role in the thermotolerance observed in the flocculating strains. Indeed, more effort must be made to clarify these technologically important physiological traits.

\section{ACKNOWLEDGEMENTS}

The authors express their gratitude to Benjamín Ayil Gutiérrez, PhD for his support in the HPLC analysis and to Merlin Burgess for proofreading the article.

\section{CONFLICT OF INTEREST}

The authors declare that the research was conducted in the absence of any commercial or financial relationships that could be construed as a potential conflict of interest.

\section{FUNDING}

This study was supported by the projects CONACYT Fomix-Tam: 193682 and Ciencia Básica 2013-221289, and the Instituto Politécnico Nacional: SIP-IPN: project 2018-0983.

\section{SUPPLEMENTARY MATERIAL}

All supplementary material is available at www.ftb.com.hr

\section{ORCID ID}

I. Vergara-Álvarez @ https://orcid.org/0000-0002-3070-5365 F. Quiroz-Figueroa (ㄱ https://orcid.org/0000-0002-1950-4810 M. C. Tamayo-Ordóñez (1) https://orcid.org/0000-0003-0201-0184 A. A. Oliva-Hernández (1) https://orcid.org/0000-0002-8904-2164 C. P. Larralde-Corona ㄴ https://orcid.org/0000-0001-9931-6037 J. A. Narváez-Zapata (ํ) https://orcid.org/0000-0003-0577-9546

\section{REFERENCES}

1. Bester MC, Pretorius IS, Bauer FF. The regulation of Saccharomyces cerevisiae FLO gene expression and $\mathrm{Ca}^{2+}$-dependent flocculation by Flo8p and Mss11p. Curr Genet. 2006; 49(6):375-83.

https://doi.org/10.1007/s00294-006-0068-z 
2. Páez JB, Córdova E, Soto Ó, Barrio E, Belloch C, Rutiaga-Quiñones OM. Saccharomyces cerevisiae strains with robust responses to fermentation stresses isolated from the alcoholic fermentation of Agave duranguensis musts. Afr J Microbiol Res. 2011;5(8):865-71. https://doi.org/10.5897/AJMR10.559

3. Arroyo-López FN, Querol A, Barrio E. Application of a substrate inhibition model to estimate the effect of fructose concentration on the growth of diverse Saccharomyces cerevisiae strains. J Ind Microbiol Biotechnol. 2009;36(5):663-9. https://doi.org/10.1007/s10295-009-0535-X

4. Oliva Hernández AA, Taillandier P, Reséndez-Pérez $D$, Narváez-Zapata JA, Larralde-Corona CP. The effect of hexose ratios on metabolite production in Saccharomyces cerevisiae strains obtained from the spontaneous fermentation of mezcal. Antonie van Leeuwenhoek. 2013;103(4):833-43. https://doi.org/10.1007/s10482-012-9865-1

5. Fleet GH. Wine yeasts for the future. FEMS Yeast Res. 2008; 8(7):979-95. https://doi.org/10.1111/j.1567-1364.2008.00427.x

6. Cheng C, Zhang M, Xue C, Bai F, Zhao X. Development of stress tolerant Saccharomyces cerevisiae strains by metabolic engineering: New aspects from cell flocculation and zinc supplementation. J Biosci Bioeng. 2017;123(2):141-6.

https://doi.org/10.1016/j.jbiosc.2016.07.021

7. Peter J, De Chiara M, Friedrich A, Yue JX, Pflieger D, Bergström A, et al. Genome evolution across 1,011 Saccharomyces cerevisiae isolates. Nature. 2018;556:339-44. https://doi.org/10.1038/s41586-018-0030-5

8. Yalcin SK, Ozbas ZY. Effects of $\mathrm{pH}$ and temperature on growth and glycerol production kinetics of two indigenous wine strains of Saccharomyces cerevisiae from Turkey. Brazilian J Microbiol. 2008;39(2):325-32.

https://doi.org/10.1590/S1517-83822008000200024

9. Borrull A, Poblet M, Rozès N. New insights into the capacity of commercial wine yeasts to grow on sparkling wine media. Factor screening for improving wine yeast selection. Food Microbiol. 2015;48:41-8. https://doi.org/10.1016/j.fm.2014.12.006

10. Tofalo R, Perpetuini G, Di Gianvito P, Arfelli G, Schirone M, Corsetti A, Suzzi G. Characterization of specialized flocculent yeasts to improve sparkling wine fermentation. J Appl Microbiol. 2016;120(6):1574-84.

https://doi.org/10.1111/jam.13113

11. De la Torre-González FJ, Narváez-Zapata JA, López-y-López VE, Larralde-Corona CP. Ethanol tolerance is decreased by fructose in Saccharomyces and non-Saccharomyces yeasts. LWT - Food Sci Technol. 2016;67:1-7. https://doi.org/10.1016/j.lwt.2015.11.024

12. Dumont A, Raynal C, Raginel F, Ortiz-Julien A. The ability of wine yeast to consume fructose. Wineland Magazine.
2008;110-13. Available from: https://www.lallemandwine. com/wp-content/uploads/2017/06/Ability-of-Wine-Yeastto-Consume-Fructose.pdf.

13. Rossouw D, Bagheri B, Setati ME, Bauer FF. Co-flocculation of yeast species, a new mechanism to govern population dynamics in microbial ecosystems. PLoS ONE. 2015;10(8): e0136249.

https://doi.org/10.1371/journal.pone.0136249

14. Kobayashi N, McEntee K. Evidence for a heat shock transcription factor-independent mechanism for heat shock induction of transcription in Saccharomyces cerevisiae. Proc Natl Acad Sci USA. 1990;87(17):6550-4.

https://doi.org/10.1073/pnas.87.17.6550

15. Gasch AP, Spellman PT, Kao CM, Carmel-Harel O, Eisen $M B$, Storz G, et al. Genomic expression programs in the response of yeast cells to environmental changes. Mol Biol Cell. 2000;11(12):4241-57.

https://doi.org/10.1091/mbc.11.12.4241

16. Van Mulders SE, Ghequire M, Daenen L, Verbelen PJ, Verstrepen KJ, Delvaux FR. Flocculation gene variability in industrial brewer's yeast strains. Appl Microbiol Biotechnol. 2010;88(6):1321-31.

https://doi.org/10.1007/s00253-010-2843-5

17. Tofalo R, Perpetuini G, Di Gianvito P, Schirone M, Corsetti A, Suzzi G. Genetic diversity of FLO1 and FLO5 genes in wine flocculent Saccharomyces cerevisiae strains. Int J Food Microbiol. 2014;191:45-52.

https://doi.org/10.1016/j.ijfoodmicro.2014.08.028

18. Bony M, Thines-Sempoux D, Barre P, Blondin B. Localization and cell surface anchoring of the Saccharomyces cerevisiae flocculation protein Flo1p. J Bacteriol. 1997;179(15): 4929-36.

https://doi.org/10.1128/jb.179.15.4929-4936.1997

19. Soares EV. Flocculation in Saccharomyces cerevisiae: A review. J Appl Microbiol. 2011;110(1):1-18.

https://doi.org/10.1111/j.1365-2672.2010.04897.x

20. Speers RA, Wan Y, Jin Y, Stewart RJ. Effects of fermentation parameters and cell wall properties on yeast flocculation. J Inst Brew. 2006;112:246-54.

https://doi.org/10.1002/j.2050-0416.2006.tb00720.x

21. Soares EV, Vroman A. Effect of different starvation conditions on the flocculation of Saccharomyces cerevisiae. J Appl Microbiol. 2003;95(2):325-30.

https://doi.org/10.1046/j.1365-2672.2003.01979.x

22. Claro FB, Rijsbrack K, Soares EV. Flocculation onset in Saccharomyces cerevisiae: Effect of ethanol, heat and osmotic stress. J Appl Microbiol. 2007;102(3):693-700.

https://doi.org/10.1111/j.1365-2672.2006.03130.x

23. Govender P, Domingo JL, Bester MC, Pretorius IS, Bauer FF. Controlled expression of the dominant flocculation genes FLO1, FLO5, and FLO11 in Saccharomyces cerevisiae. Appl 
Environ Microbiol. 2008;74(19):6041-52.

https://doi.org/10.1128/AEM.00394-08

24. Zara S, Bakalinsky AT, Zara G, Pirino G, Demontis MA, Budroni M. FLO11-based model for air-liquid interfacial biofilm formation by Saccharomyces cerevisiae. Appl Environ Microbiol. 2005;71(6):2934-9.

https://doi.org/10.1128/AEM.71.6.2934-2939.2005

25. Di Gianvito P, Tesnière C, Suzzi G, Blondin B, Tofalo R. FLO5 gene controls flocculation phenotype and adhesive properties in a Saccharomyces cerevisiae sparkling wine strain. Sci Rep. 2017;7(1):10786.

https://doi.org/10.1038/s41598-017-09990-9

26. Di Gianvito P, Tesnière C, Suzzi G, Blondin B, Tofalo R. Different genetic responses to oenological conditions between a flocculent wine yeast and its FLO5 deleted strain: Insights from the transcriptome. Food Res Int. 2018;114:178-86.

https://doi.org/10.1016/j.foodres.2018.07.061

27. Wood IP, Elliston A, Ryden P, Bancroft I, Roberts IN, Waldron $\mathrm{KW}$. Rapid quantification of reducing sugars in biomass hydrolysates: Improving the speed and precision of the dinitrosalicylic acid assay. Biomass Bioenerg. 2012;44:117-21. https://doi.org/10.1016/j.biombioe.2012.05.003

28. Ogata T. Nitrogen starvation induces expression of Lg-FLO1 and flocculation in bottom-fermenting yeast. Yeast. 2012; 29(11):487-94. https://doi.org/10.1002/yea.2928

29. Tamura K, Dudley J, Nei M, Kumar S. MEGA4: Molecular evolutionary genetics analysis (MEGA) software version 4.0. Mol Biol Evol. 2007;24(8):1596-9.

https://doi.org/10.1093/molbev/msm092

30. Teste MA, Duquenne M, François JM, Parrou JL. Validation of reference genes for quantitative expression analysis by real-time RT-PCR in Saccharomyces cerevisiae. BMC Mol Biol. 2009;10:99.

https://doi.org/10.1186/1471-2199-10-99
31. Pfaffl MW. A new mathematical model for relative quantification in real-time RT-PCR. Nucleic Acids Res. 2001;29(9): e45. https://doi.org/10.1093/nar/29.9.e45

32. Statistica, v. 8.0, StatSoft, Inc, Tulsa, OK, USA; 2008. Available from: http://www.statsoft.com/Products/STATISTICAFeatures.

33. Guillaume C, Delobel P, Sablayrolles JM, Blondin B. Molecular basis of fructose utilization by the wine yeast Saccharomyces cerevisiae: A mutated HXT3 allele enhances fructose fermentation. Appl Environ Microbiol. 2007;73(8):2432-9. https://doi.org/10.1128/AEM.02269-06

34. Bauer EF, Pretorius LS. Yeast stress response and fermentation efficiency: How to survive the making of wine - A Review. S Afr J Enol Vitic. 2000;21:27-51.

https://doi.org/10.21548/21-1-3557

35. Torbensen R, Møller HD, Gresham D, Alizadeh S, Ochmann $D$, Boles E, Regenberg B. Amino acid transporter genes are essential for FLO11-dependent and FLO11-independent biofilm formation and invasive growth in Saccharomyces cerevisiae. PLoS ONE. 2012;7(7):e41272.

https://doi.org/10.1371/journal.pone.0041272

36. Hoch HC, Galvani CD, Szarowski DH, Turner JN. Two new fluorescent dyes applicable for visualization of fungal cell walls. Mycologia. 2005;97(3):580-8.

https://doi.org/10.1080/15572536.2006.11832788

37. Teunissen AW, Steensma HY. The dominant flocculation genes of Saccharomyces cerevisiae constitute a new subtelomeric gene family. Yeast. 1995;11(11):1001-13. https://doi.org/10.1002/yea.320111102

38. Bayly JC, Douglas LM, Pretorius IS, Bauer FF, Dranginis AM. Characteristics of Flo11-dependent flocculation in Saccharomyces cerevisiae. FEMS Yeast Res. 2005;5(12):1151-6. https://doi.org/10.1016/j.femsyr.2005.05.004

39. Li J, Wang L, Wu X, Fang O, Wang L, Lu C, et al. Polygenic molecular architecture underlying non-sexual cell aggregation in budding yeast. DNA Res. 2013;20(1):55-66. https://doi.org/10.1093/dnares/dss033 